\title{
Hotel Guest Satisfaction and Service Quality: Evidence from Czech Safari Hotel
}

\author{
Petr SCHOLZ ${ }^{1 *}$, Ivica LINDEROVÁ2, Petr JANEČEK ${ }^{3}$ \\ 1,2Assistant professor, PhD, College of Polytechnics Jihlava, Czechia. \\ E-mail: petr.scholz@vspj.cz¹, ivica.linderova@vspj.cz² \\ ${ }^{3}$ Assistant professor, PhD, University of West Bohemia, Czechia; E-mail: janecp00@kmo.zcu.cz \\ ${ }^{*}$ Corresponding Author
}

\begin{abstract}
Received: 08.09.2021
Accepted: 23.11.2021

Published: 02.12.2021

DOI: 10.47750/QAS/22.185.28

Abstract

The development of accommodation facilities is currently (especially in the COVID-19 pandemic) accompanied by a growth in guests' emphasis on the quality and structure of additional services. Guest satisfaction with services in tourism is thus one of the important factors affecting the level of profitability, prosperity, and competitiveness. The quality of accommodation facilities is related to the satisfaction of guests. The proper attitude and professionalism are the key success factors along with the quality of the services provided by any accommodation facility. The guests' perception of quality is influenced by the professionalism, helpfulness, and willingness of the staff. The goal of this paper was to evaluate guest satisfaction with accommodation, catering, and additional services at a selected hotel in Dvưr Králové nad Labem. Guest satisfaction was determined using a questionnaire survey conducted from July 2018 to January 2019. The results were evaluated by means of a cluster analysis in the Statistica 13 EN software application. The greatest dissatisfaction was expressed in summer with air-conditioning in rooms. Furthermore, the worst rating concerned the quality of food and beverages with respect to their price, which did not meet guests' expectations. The lowest satisfaction expressed by guests was with the value for money in terms of the quality of additional services, which they perceived as part of the value for money ratio with respect to room rates.
\end{abstract}

Keywords: guest satisfaction; service quality; hotel, complaint, Czechia.

\section{Introduction}

The current trend in the accommodation market goes hand in hand with an increase in guests' expectations in terms of the quality and structure of additional services (Anderson \& Srinivasan, 2003; Baker \& Crompton, 2000). Lately, the word 'quality' has been used ever more often. In 2003, the United Nations World Tourism Organization (UNWTO) defined quality as "the result of a process which implies the satisfaction of all tourism product and service needs, requirements and expectations of the consumer at an acceptable price, in conformity with mutually accepted contractual conditions and the implicit underlying factors such as safety and security, hygiene, accessibility, authenticity and concerns over the impact of tourism activities on the natural and cultural environment." The international ISO 9001 standard defines quality as "the degree to which a set of inherent characteristics of an object fulfils requirements". According to this standard, requirements are either expected (e.g., by hotel guests) or binding (e.g., based on legislation).

Guests increasingly often visit high-quality hotels and expect high-quality food in restaurants; suppliers sell highquality goods to hotels and hotels hire high-quality staff that provide high-quality service, etc. (Hán et al., 2016). The quality of services is considered to be a key element affecting guest satisfaction and loyalty. The quality of services also affects a hotel's marketability and prosperity (Lee \& Cheng, 2018). Baloglu (2002), Bowen \& Shoemaker (2003) state that ensuring guest satisfaction is the goal of all operators of accommodation facilities.

Guest satisfaction is the subject of psychological research. It can be characterized as the degree to which a guest perceives his or her requirements to be met (Gúčik, 2010). Guest satisfaction in accommodation facilities is linked to the care that staff of the accommodation facility provide to guests (Němčanský, 1995). Many hotel managers agree that guests should feel they got some added value which they had not expected to get. This motivates them to return to the accommodation facility in the future (Scholz, 2014). Guest satisfaction in hotels is addressed by Das et al. (2017) and Paulose and Shakeel (2021); guest satisfaction in hotels chains is covered by Barthélemy et al. (2021), AirBnB (Ruan, 2020). It needs to be said that there are differences in guest satisfaction between independent hotels and hotels chains (Moreno-Perdigón et al, 2021). Guest satisfaction with services provided by tourism businesses is one of the significant factors affecting companies' revenue and profit, prosperity, position in the competitive environment, etc. Equally important, along with the quality of services, is the attitude and professionalism of staff. Their professionalism, helpfulness and willingness affect the guests' perception of the product (Linderová \& Gúčik, 2011). Accommodation facilities often believe that their guests are satisfied if they do not 


\section{GENERAL MANAGEMENT}

receive any complaints. This is not always the case and not even high-quality services necessarily lead to complete guest satisfaction. In general, quality is the fundamental prerequisite for customer satisfaction and customer satisfaction is a prerequisite for guests coming back in the future (Clemes et al., 2010; Gracia et al., 2011; Gúčik et al., 2007).

Quality is defined as the degree or standard of perfection. The quality of services offered and provided is not a matter of chance, but the result of hard work (Hán et al., 2016). However, it cannot be understood as the highest degree possible, as something of supreme quality and the highest price, because guests may expect and be happy even with a simple restaurant menu (Linderová \& Gúčik, 2011). The quality of hotel management significantly affects the quality of accommodation as well as catering services (Faktorová, 2019; Janičková et al., 2006). Hán et al. (2016) claim that a quality management system is about setting rules and establishing order, about creating a form to be filled with content guests and motivated employees. It is a proven fact that flaws in hotels and hotel restaurants are in $85 \%$ of cases caused by deficiencies of the system while only $15 \%$ of problems are caused by the employees responsible. Gúčik et al. (2016); Hán et al. (2016); Linderová \& Gúčik (2011); Křížek \& Neufus (2014); Rašovská \& Ryglová (2017); Sysel (2019); Vodáček \& Vodáčková (2006) state that there are usually concepts of quality systems used in quality assurance: (1) standards pertaining to the amenities and services (product standards), quality control, which is based on (2) the ISO 9000 series of standards and (3) total quality management (TQM).

Reception staff should pay close attention to guests' complaints and comments and try to achieve a result that is satisfactory for both sides. If an upset guest approaches the front desk to express a complaint, it is crucial that the reception staff let them speak, pay attention and refrain from interrupting them. This should result in the guest calming down and allowing room for a constructive solution. If the receptionist does not succeed, he or she should call their supervisor, or possibly the hotel manager. Guests' complaints are an indication that there is something wrong with the hotel and they are often useful for the hotel. That is why some hotels ask their guests for feedback and suggestions for further improvements to their services (Stárek \& Vaculka, 2008). It is important to understand that complaints are beneficial in providing quality services. Long (2006) states that only $4 \%$ of dissatisfied guests complain directly at the accommodation facility. Dissatisfied guests share their negative experience, on average, with ten relatives, friends, acquaintances and even strangers. Of these, $13 \%$ will further share it with another 20 people, so news of this negative experience may in the end get to as many as 1,560 people. Besides that, thanks to social media, this number can easily climb much higher.

It is worth pointing out that there are different categories of complaining guests (Table 1) with whom staff come into contact. Therefore, they should know how to communicate with a difficult customer (Gúčik et al., 2007).

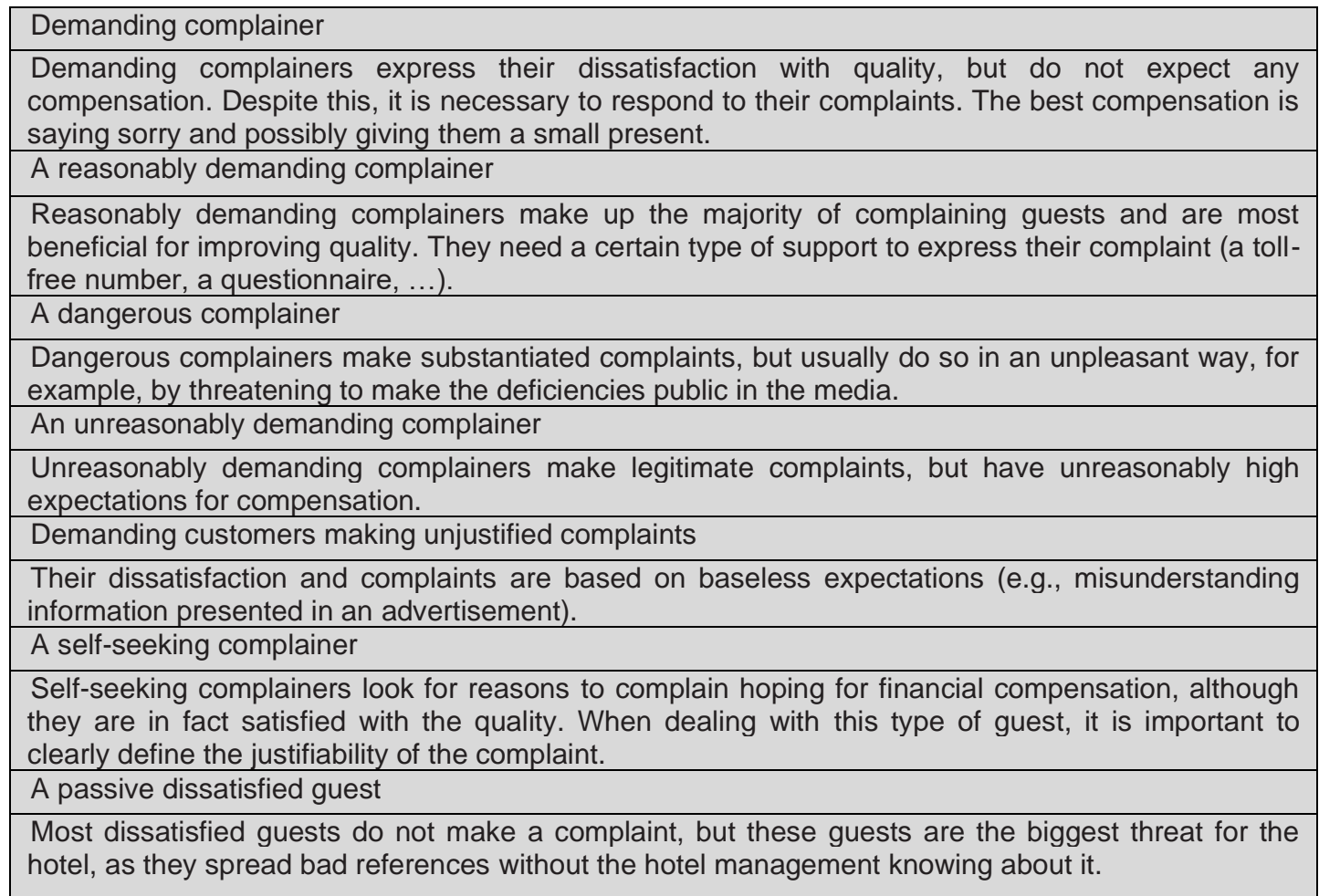

Table 1: Typology of complaining guests

Source: Processed by Gúčik et al., 2007.

If a complaint is found to be justified, a remedy must be provided to the guest (Table 2). The greater the guest is put out (materially, psychologically), the more difficult and financially demanding it is to compensate them. A hotel should have a system of compensations in place in order to resolve complaints, including assigned competencies specifying in what cases the complaint may be resolved by a member of staff in direct contact with the guest as opposed to cases when it must be handled by a member of hotel staff in charge of resolving guests' complaints (Gúčik et al., 2016). 


\begin{tabular}{|l|l|}
\hline Non-material & - a verbal apology \\
& - a written apology \\
& - an apology conveyed over the phone \\
\hline Material & - a voucher for a service (e.g., new services provided in the hotel, free cosmetics services) \\
(service) & - providing higher-standard services (e.g., a suite instead of an unavailable deluxe double room) \\
& - a trip \\
& - a ticket to an amusement park or a cultural or sports event \\
\hline $\begin{array}{l}\text { Material } \\
\text { (gift) }\end{array}$ & - a voucher for food and beverages \\
\hline $\begin{array}{l}\text { Financial } \\
\text { remedy }\end{array}$ & - a bottle of wine, a bottle of sparkling wine \\
& - a souvenir \\
\hline
\end{tabular}

Table 2: Compensation tools

Source: Processed by Gúčik et al., 2007.

In most cases, guests whose complaints were resolved to their satisfaction become the most loyal customers and spread the good name of the hotel. For various reasons, most hotel guests do not voice their complaints. They do not know who to turn to and assume that it would be pointless and that the hotel would not deal with their complaint. They consider the complaint handling procedure too complicated and are afraid that as a result of their complaint the service provided might even get worse (Long, 2006). There are a number of models explaining the essence of guest satisfaction (e.g., the European Customer Satisfaction Index, GAP analysis, Kano mode, a model of possible responses, etc.). These models are not mutually exclusive, but rather complement one another. They also imply that guest satisfaction is not merely a result, but a certain process (Gúčik et al., 2007). It is used not only to ensure a degree of guest satisfaction, but also serves as a tool for hotel management to put measures in place required in order to improve their hotel.

\section{Materials and Methods}

The hotel that was selected for the purposes of this article is located in Dvưr Králové nad Labem and is part of the famous local zoo with its African and Lion Safari. It is a Standard class hotel with the designation Superior. There is a restaurant with its own brewery available to guests. The hotel includes a campground and together they form a resort. The goal of the article was to evaluate satisfaction with accommodation, catering, and additional services in Dvưr Králové nad Labem. In connection with this goal, the following research question was posed: In which areas, in terms of the satisfaction of guests staying at the said accommodation facility, was customer satisfaction the lowest? Satisfaction was determined using a questionnaire survey which was conducted from July 2018 to January 2019. The collection of primary data was preceded by literature research. Following the completion of the theoretical basis for this article, the research itself was conducted. It was divided into three parts the pilot study, pre-research, and data collection (Disman, 2002; Hendl, 2012). The questionnaires were put in hotel rooms so that guests would have enough time to fill them out. The 2-page questionnaire contained 6 questions with subquestions about the various criteria in the areas of accommodation, catering, and additional services. These items were evaluated by respondents $(n=198$, Table 3 ) on the Likert scale (1-5). Mark 1 represented the highest satisfaction and 5 the lowest. The evaluation was further carried out by means of a cluster analysis using the Statistica 10 EN software application. One of the most common ways of expressing similarity relations between objects are metrics based on a geometric data model. If we assign to objects characterized by $p$ features as models points of a $p$ dimensional Euclidean space Ep, then the Euclidean distance between two points $(r, s)$ is defined as follows (Lukasová \& Šarmanová, 1985):

$$
\delta(r, s)=\left[\sum_{i=1}^{p}\left(x_{r i}-x_{s i}\right)^{2}\right]^{1 / 2}
$$

\begin{tabular}{|l|l|}
\hline Criteria & $\%$ \\
\hline Gender & 33 \\
\hline Male & 61 \\
\hline Female & 6 \\
\hline I do not wish to express my opinion & \\
\hline Length of stay & 36 \\
\hline 1 night & 56 \\
\hline $2-3$ nights & 6 \\
\hline $4-5$ nights & 1 \\
\hline $6-7$ nights & 1 \\
\hline Extended stay & \\
\hline Age & 11 \\
\hline Up to 18 years & 7 \\
\hline $18-30$ years & 25 \\
\hline $31-40$ years & 25 \\
\hline $41-54$ years &
\end{tabular}


GENERAL MANAGEMENT

\begin{tabular}{|l|l|}
\hline $55-65$ years & 9 \\
\hline Over 65 years & 2 \\
\hline I do not wish to say & 21 \\
\hline Achieved education & \\
\hline Primary school & 6 \\
\hline Vocational school (certificate of apprenticeship) & 10 \\
\hline High school (maturita) & 38 \\
\hline College & 4 \\
\hline University & 32 \\
\hline I do not wish to say & 10 \\
\hline
\end{tabular}

Table 3: Sample of respondents

Source: Own elaboration, 2021.

\section{Results and discussion}

In terms of accommodation services, guests were very satisfied. $89 \%$ of them found the hotel's location satisfactory, mostly because the hotel is part of the zoo with its African and Lion Safari. $84 \%$ of the guests were satisfied with booking their accommodation; most guests made their reservation using the online reservation form or by email. Satisfaction with check-in reached $88 \%$. Although check-in is after 2 p.m., if the room has been cleaned and is ready for the next guest, the receptionist tries to accommodate clients and checks them in earlier. If an earlier check-in is not possible, guests are at least provided with wristbands for free entry into the walking area of the zoo, allowing them to stroll through the entire walking part of the zoo before checking into the hotel. As for the behavior of the reception staff, most respondents were completely satisfied, with the satisfaction score reaching 95\% in this criterion. Receptionists did their best to be helpful and friendly and accommodate guests' wishes. The behavior of the hotel maids was also viewed very positively. They were always around and available to help with cleaning or any other requests concerning room service. Another criterion was the professionalism of the staff, which also received a positive rating of $88 \%$, which was the same result as satisfaction with the behavior of the housekeeping staff. This shows that the staff at this accommodation facility tried to accommodate guests and fulfill their requests every time it was possible. A slightly lower guest satisfaction at $77 \%$ was with the size and lighting of rooms. Family, double rooms with extra beds and wheelchair accessible rooms are smaller compared to hotel suites. Some rooms are rather dark even with proper lighting. The lowest satisfaction score in terms of accommodation services went to heating and air-conditioning. $49 \%$ of the respondents were satisfied when it comes to this criterion. As far as heating goes, the questionnaires reported positive feedback even on cold days, but on hot days the guests were not very satisfied as some rooms do not have air-conditioning at all. This is one of the reasons why the hotel is rated in the 3 star Superior category. On the other hand, guests were very satisfied with the hotel telephone system, the rating in this criterion reaching $90 \%$. In terms of the hotel TV service, the satisfaction rate dropped slightly, mostly because of the limited selection of TV channels for children. Thanks to the proximity of the hotel to the zoo, a large number of children stay at the hotel, which resulted in the satisfaction score being only $72 \%$. Storage facilities were rated quite positively and when it came to this criterion, the respondents' satisfaction was $80 \%$. What this hotel prides itself on is cleanliness, so it is no wonder that guest satisfaction with room cleanliness reached $95 \%$, with satisfaction in terms of bathroom cleanliness being even higher, at $97 \%$, which represented the highest satisfaction score in the areas of accommodation, catering, and additional services. The rooms are well-equipped, which corresponded with $82 \%$ of respondents being satisfied with the room amenities. Most respondents voiced no problem with the check-out time being before 10 a.m., and this criterion received a $78 \%$ satisfaction score. $74 \%$ of respondents were satisfied with room cleaning during their stay, although this figure was largely affected by the fact that many guests did not know that they needed to put a sign on the door to request that their room be cleaned, which led to a lower satisfaction score than that of room cleanliness upon check-in. Slightly more than half of the respondents $(57 \%)$ were satisfied in terms of the value for money criterion, which is not a high score, but it needs to be noted that especially during the summer holidays the rooms are in high demand and the occupancy rate is very high, which may have resulted in higher room rates (Table 4, Figure 1).

\begin{tabular}{|c|c|c|c|c|c|c|c|}
\hline Criteria (\%) & Means & Std. Dev. & (2):-) & (;) & :) & (2) & (2) \\
\hline Localization & 4.878788 & 0.356882 & 89 & 10 & 1 & 0 & 0 \\
\hline Reservation of accommodation & 4.782828 & 0.550319 & 84 & 10 & 5 & 1 & 0 \\
\hline Check-in & 4.838384 & 0.517845 & 88 & 9 & 1 & 2 & 0 \\
\hline Staff behavior (reception) & 4.944444 & 0.270259 & 95 & 4 & 1 & 0 & 0 \\
\hline Behavior of maids & 4.808081 & 0.647945 & 88 & 9 & 1 & 0 & 2 \\
\hline Professionalism of staff & 4.858586 & 0.403289 & 88 & 10 & 2 & 0 & 0 \\
\hline Room size & 4.696970 & 0.644454 & 77 & 17 & 4 & 1 & 1 \\
\hline Lighting & 4.707071 & 0.608777 & 77 & 17 & 5 & 0 & 1 \\
\hline Heating/AC & 3.838384 & 1.397656 & 49 & 16 & 16 & 8 & 11 \\
\hline Hotel telephone & 4.863636 & 0.457970 & 90 & 6 & 3 & 1 & 0 \\
\hline TV offer & 4.585859 & 0.740560 & 72 & 17 & 9 & 2 & 0 \\
\hline Storage facilities & 4.747475 & 0.593423 & 80 & 16 & 2 & 1 & 1 \\
\hline Room cleanliness & 4.929293 & 0.370280 & 95 & 3 & 1 & 1 & 0 \\
\hline
\end{tabular}




\section{GENERAL MANAGEMENT}

\begin{tabular}{|l|l|l|l|l|l|l|l|}
\hline Cleanliness of bathroom & 4.954545 & 0.338636 & 97 & 2 & 1 & 0 & 1 \\
\hline Room amenities & 4.787879 & 0.509259 & 82 & 15 & 2 & 1 & 0 \\
\hline Check-out & 4.702020 & 0.626890 & 78 & 15 & 6 & 1 & 0 \\
\hline Cleaning during the stay & 4.368687 & 1.274677 & 74 & 10 & 4 & 2 & 10 \\
\hline Room price vs. quality & 4.404040 & 0.805050 & 57 & 29 & 11 & 2 & 1 \\
\hline
\end{tabular}

(:);- very satisfied (1), $:-$ - satisfied $(2),-;$ - neutral (neither satisfied nor dissatisfied) (3),

$\because:$ - dissatisfied (4), :: $:$ - very dissatisfied (5)

Table 4: Evaluation of accommodation services

Source: Own elaboration, 2021.

Tree Diagram for 18 Variables

Single Linkage

Euclidean distances

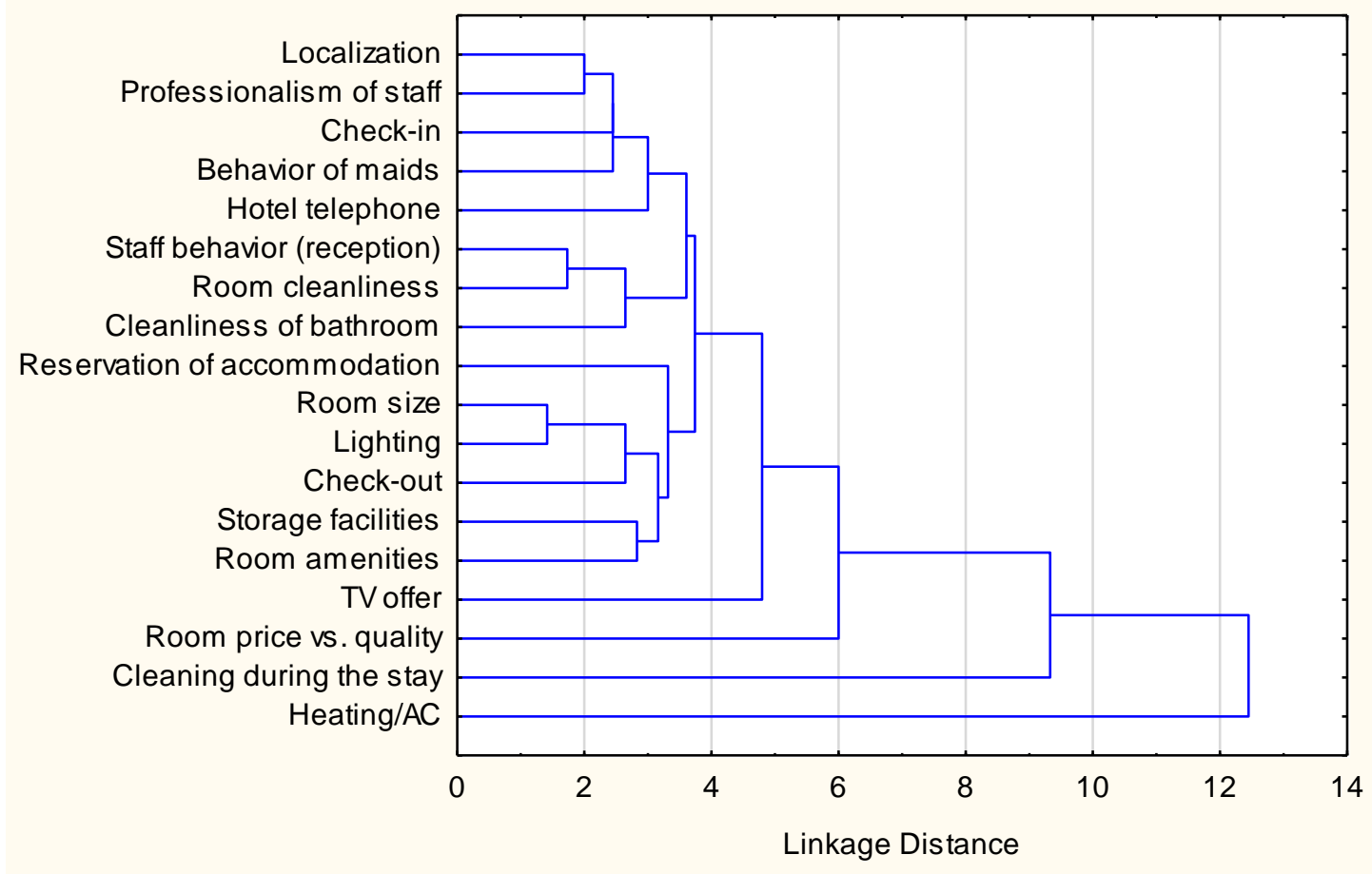

Figure 1: Evaluation of accommodation services Source: Own elaboration, 2021.

In most cases, the guests were also satisfied with the hotel's catering services. There were only a few cases of negative feedback. The cost of accommodation in all hotel rooms includes the breakfast buffet, so everyone had the chance to evaluate the quality of breakfast in the questionnaire, in which $76 \%$ of respondents said they were satisfied with the quality and variety of food at breakfast. More than half of the respondents, precisely $55 \%$, were satisfied with the lunch menu. Less than half of the respondents (48\%) were satisfied with their dinner menus. The satisfaction score was much lower compared to guest satisfaction with breakfast because of the smaller and less varied selection of dishes at lunchtime and dinnertime. The quality of food compared to the previous two offers rarely increased to $62 \%$. $71 \%$ of respondents expressed satisfaction with the quality of beverages. A mere $36 \%$ of respondents were satisfied with the value for money ratio for food and beverages, which is the lowest satisfaction score of all the accommodation, catering, and additional services. Given the result, the quality of food should increase to correspond to its price. Satisfaction with the behavior and professionalism of the restaurant staff at $77 \%$ and $79 \%$ were above-average, mainly because staff members always tried to accommodate guests' requests. $79 \%$ of respondents were satisfied with the dining atmosphere, which is also viewed as a positive rating. In terms of catering services, the highest satisfaction score went to restaurant cleanliness, which the restaurant, just like the hotel, prides itself on, hence in this criterion the satisfaction score reached $88 \% .81 \%$ of respondents expressed their satisfaction with the cleanliness of dishware (Table 5, Figure 2). 


\section{GENERAL MANAGEMENT}

\begin{tabular}{|c|c|c|c|c|c|c|c|}
\hline Criteria (\%) & Means & Std. Dev. & (;) (;) & (;) & :) & (2) & 2:2 \\
\hline Breakfast offer & 4.707071 & 0.591866 & 76 & 19 & 4 & 0 & 1 \\
\hline Restaurant menu at lunch time & 4.282828 & 0.934835 & 55 & 24 & 15 & 5 & 1 \\
\hline Restaurant menu at dinner time & 4.151515 & 0.975472 & 48 & 25 & 21 & 5 & 1 \\
\hline $\begin{array}{l}\text { Food quality (temperature, consistency, } \\
\text { appearance) }\end{array}$ & 4.464646 & 0.834694 & 62 & 27 & 7 & 2 & 2 \\
\hline Drink quality & 4.585859 & 0.760845 & 71 & 19 & 8 & 1 & 1 \\
\hline Behavior of staff & 4.691919 & 0.638077 & 77 & 16 & 5 & 2 & 0 \\
\hline Dining atmosphere & 4.686869 & 0.615312 & 75 & 21 & 2 & 2 & 0 \\
\hline Staff professionalism & 4.696970 & 0.690097 & 79 & 14 & 4 & 2 & 1 \\
\hline Cleanliness of the restaurant & 4.818182 & 0.593769 & 88 & 9 & 1 & 1 & 1 \\
\hline Cleanliness of dishes & 4.777778 & 0.524633 & 81 & 16 & 2 & 0 & 1 \\
\hline Price of drinks and meals vs. quality & 3.888889 & 1.098119 & 36 & 31 & 21 & 8 & 4 \\
\hline
\end{tabular}

;:) - very satisfied (1), $;$ - - satisfied (2), $: ;$ - neutral (neither satisfied nor dissatisfied) (3),

$: 0$ - dissatisfied (4), : : - very dissatisfied (5)

Table 5: Evaluation of catering services

Source: Own elaboration, 2021.

Tree Diagram for 11 Variables

Single Linkage

Euclidean distances

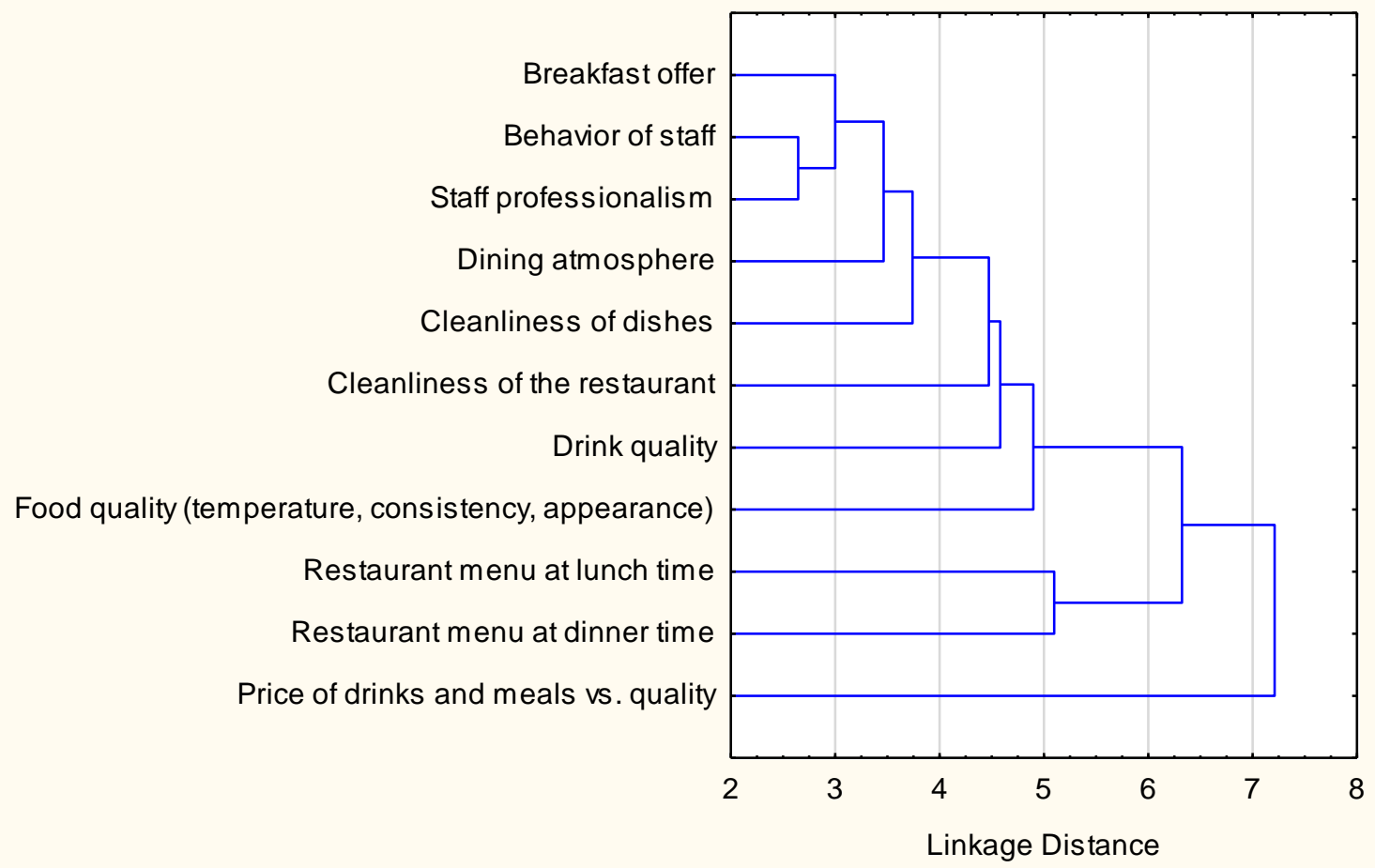

Figure 2: Evaluation of accommodation services Source: Own elaboration, 2021.

Additional services available to hotel guests included Wi$\mathrm{Fi}$, a swimming pool, bowling, the zoo, and customer parking. The only service that was not provided free of charge was bowling; the remaining services were included in the cost of accommodation, although the free zoo access included only the walking paths. Most guests were satisfied with the hotel's additional services. The hotel $\mathrm{Wi}-\mathrm{Fi}$ received a $69 \%$ satisfaction score, the lower figure caused by a less than optimum internet connection in some rooms. $72 \%$ of respondents were satisfied with the hotel pool. As many as $86 \%$ of guests were happy with the hotel bowling alley with four shorter lanes. The highest satisfaction among guests was with the zoo, which is usually the main reason for choosing to stay at this hotel. More than half of the respondents $(61 \%)$ were satisfied with the value for money ratio. The parking lot for guests is situated right outside the hotel entrance, which resulted in an $86 \%$ satisfaction score (Table 6). 


\section{GENERAL MANAGEMENT}

\begin{tabular}{|c|c|c|c|c|c|c|c|}
\hline Criteria (\%) & Means & Std. Dev. & (2):(); & (:) & () & (2) & (2) \\
\hline Wi-Fi & 4.454545 & 0.979721 & 69 & 16 & 8 & 4 & 3 \\
\hline Swimming pool & 4.666667 & 0.604551 & 72 & 23 & 4 & 0 & 1 \\
\hline Bowling & 4.848485 & 0.386672 & 86 & 13 & 1 & 0 & 0 \\
\hline $\mathrm{ZOO}$ & 4.909091 & 0.429636 & 94 & 3 & 2 & 0 & 1 \\
\hline Parking & 4.790000 & 0.624338 & 86 & 10 & 2 & 1 & 1 \\
\hline Price vs. quality of additional services & 4.470000 & 0.784380 & 61 & 28 & 9 & 1 & 1 \\
\hline
\end{tabular}

(:):- very satisfied (1), :-; - satisfied (2), $:-$ - neutral (neither satisfied nor dissatisfied) (3),

$: 0$ - dissatisfied (4), : : - very dissatisfied (5)

Table 6. Evaluation of additional services

Source: Own elaboration, 2021.

\section{Conclusions}

The aim of the article was to evaluate guest satisfaction with accommodation, catering, and additional services at a selected hotel in Dvůr Králové nad Labem. In connection with this aim, the following research question was posed: In which areas, in terms of the satisfaction of guests staying at the said accommodation facility, was customer satisfaction the lowest?

Satisfaction with the accommodation services was very high. The lowest satisfaction score was that for airconditioning in the summertime (49\% satisfaction), although it needs to be said that this dissatisfaction was unjustified, as according to the Official Classification of Czech Accommodation Facilities, the Standard class does not require to offer air-conditioning. Guests were also somewhat dissatisfied with the value for money ratio (57\% satisfaction) and the selection of TV channels ( $72 \%$ satisfaction), with some guests requesting a wider variety of channels for their children.

With some exceptions, satisfaction with the catering services was very high. The worst satisfaction score was for the quality of food and beverages vs. their price, which did not match guests' expectations, thus in this criterion the satisfaction score reached only $36 \%$. Respondents also expressed dissatisfaction with the restaurant's offer at dinnertime (48\% satisfaction), but also at lunchtime (55\% satisfaction), most likely because of the limited selection of dishes at these times.

The additional services were assessed as satisfactory. The lowest satisfaction was with the value for money ratio in additional services, which may have been understood as part of the value for money in terms of the room rate, as all the additional services, except for bowling and refreshments at the zoo and tickets to its experience programs (e.g., the African and Lion Safari), are included in the cost of accommodation. There was also notable dissatisfaction with the hotel Wi-Fi.

The research limits can be considered that there is only one hotel and it is not possible to generalize the results. On the other hand, the owner and the general manager of the hotel were satisfied with the questionnaire survey and have already eliminated some shortcomings for higher guest satisfaction. As for the following research direction, we would like to focus on other hotels in the town and their surroundings or regions to compare the individual results. During the COVID-19 pandemics, it is more than desirable to focus on the guest and exceed his expectations. It can be done with the quality of services offered and provided, thus differentiating it from competing hotels.

\section{References}

[1] Anderson, R. E., \& Srinivasan, S. S. (2003). E-satisfaction and e-loyalty: A contingency framework. Psychology and Marketing, 20(2), 123-138. doi:10.1002/mar.10063
[2] Baker, D. A., \& Crompton, J. L. (2000). Quality, satisfaction and behavioral intentions. Annals of Tourism Research, 27(3), 785804. doi:10.1016/s0160-7383(99)00108-5

[3] Baloglu, S. (2002). Dimensions of customer loyalty: separating friends from well wishers. The Cornell Hotel and Restaurant Administration Quarterly, 43(1), 47-59. doi:10.1016/s00108804(02)80008-8

[4] Barthélemy, J., Graf, N., \& Karaburun, R. (2021). Good but not so great: The impact of chain affiliation on guest satisfaction and guest satisfaction extremeness. International Journal of $\begin{array}{lll}\text { Hospitality } & \text { Management, } & 94,\end{array}$ doi:10.1016/j.jijhm.2020.102828

[5] Bowen, J. T., \& Shoemaker, S. (2003). Loyalty: A Strategic Commitment. Cornell Hotel and Restaurant Administration Quarterly, 44(5-6), 31-46. doi:10.1177/001088040304400505

[6] Clemes, M. D., Gan, C., \& Ren, M. (2010). Synthesizing the Effects of Service Quality, Value, and Customer Satisfaction on Behavioral Intentions in the Motel Industry. Journal of Hospitality \& Tourism Research, 35(4), 530-568. doi:10.1177/1096348010382239

[7] Das, D., Chawla, U., \& Ray, S. (2017). Factors Affecting Customer Satisfaction and Service Quality in the Boutique Hotel Industry of Kolkata, West Bengal. International Journal of Management, 8(6), 130-135.

[8] Disman, M. (2002). Jak se vyrábí sociologická znalost. Praha: Karolinum.

[9] Gracia, E., Bakker, A. B., \& Grau, R. M. (2011). Positive emotions: the connection between customer quality evaluations and loyalty. Cornell Hospitality Quarterly, 52(4), 458-465.

[10] Faktorová, A. (2019). Guest satisfaction with the accommodation services of the selected accommodation facility in Dvůr Králové nad Labem. Jihlava: VSPJ.

[11] Gúčik, M. (2010). Cestovný ruch. Úvod do štúdia. Banská Bystrica: Slovak-Swiss Tourism.

[12] Gúčik, M., Gajdošík, T., \& Lencsésová, Z. (2016). Kvalita a spokojnost' zákazníka v cestovnom ruchu. Bratislava: Wolters Kluwer.

[13] Gúčik, M., Patúš, P., \& Šebová, L. (2007). Kontroling podnikov cestovného ruchu. Banská Bystrica: Dali-BB.

[14] Hán, J., Beránek, M., Belešová, S., Mrkos, D., Studnička, P., \& Sochůrková, M. (2016). Vybrané kapitoly z hotelnictví a gastronomie. Svazek druhý - Ubytovací služby. Praha: Wolters Kluwer.

[15] Hendl, J. (2012). Přehled statistických metod: Analýza a metaanalýza dat. Praha: Portál.

[16] Janičková, J., Makovník, T., \& Šebová, L.. (2006). Manažment ubytovacích služieb. Banská Bystrica: UMB.

[17] Křižek, F., \& Neufus, J. (2014). Moderní hotelový management. Praha: Grada Publishing

[18] Lee, W.-H., \& Cheng, C.-C. (2018). Less is more: A new insight for measuring service quality of green hotels. International Journal of Hospitality Management, 68, 32-40. doi:10.1016/j.ijhm.2017.09.005 


\section{GENERAL MANAGEMENT}

[19] Linderová, I., \& Gúčik, M. (2011). Hotelové štandardy ako nástroj kvality. Hotelier, 5(1), 32-42.

[20] Long, D. M. (2006). Encourage customer complaints. Learning Journey, 1(8), xx-xx.

[21] Lukasová, A., \& Šarmanová, J. (1985). Metody shlukové analýzy. Praha: SNTL.

[22] Moreno-Perdigón, M. C., Guzmán-Pérez, B., \& Ravelo Mesa, T. (2021). Guest satisfaction in independent and affiliated to chain hotels. International Journal of Hospitality Management, 94, 102812. doi:10.1016/j.ijhm.2020.102812

[23] Němčanský, M. (1995). Management služeb cestovního ruchu 1,2. Karviná: Slezská univerzita Obchodně podnikatelská fakulta Karviná.

[24] Malini Mittal Bishnoi. "Flipped classroom and digitization: an inductive study on the learning framework for 21 st century skill acquisition". Journal for Educators, Teachers and Trainers, 11, 1, 2020, 30-45. doi: 10.47750/jett.2020.11.01.004

[25] Rašovská, I., \& Ryglová, K. (2017). Management kvality služeb v cestovním ruchu. Praha: Grada Publishing.

[26] Ruan, Y. (2020). Perceived host-guest sociability similarity and participants' satisfaction: Perspectives of airbnb guests and hosts. Journal of Hospitality and Tourism Management, 45, 419-428. doi:10.1016/j.jhtm.2020.09.009

[27] Scholz, P. (2014). Spokojenost hostů se službami ve vybraných ubytovacích zařizeních v Kraji Vysočina. Ekonomika cestovného ruchu a podnikanie, 6(3), 32-44.

[28] Stárek, V., \& Vaculka, J. (2008). Školení a vzdělávání pracovníků v cestovním ruchu. Ubytovací úsek $v$ oblasti cestovního ruchu. Praha: MMR.

[29] Sysel, J. (2019). Revize mezinárodních standardů ISO řešících problematiku kvality. COT Business, 9, 56.

[30] UNWTO (2003). UNWTO Quality Support Committee at its sixth meeting. Madrid: UNWTO.

[31] Vodáček, L., \& Vodáčková, O. (2006). Moderní management $v$ teorii a praxi. Praha: Management Press 